\title{
Prevalence of Accessory Renal Artery In Aortic
}

\section{Aneurysms}

\section{Aort Anevrizmalarında Aksesuar Renal Arter Sıklığı}

\author{
Mustafa Etli ${ }^{1^{*}}$, Seda Avnioğlu ${ }^{2}$, Rumeysa Dikici ${ }^{2}$ \\ 1 Alanya Alaaddin Keykubat University Faculty of Medicine, Department of Cardiovascular Surgery, Antalya, Turkey \\ 2 Alanya Alaaddin Keykubat University Faculty of Medicine, Department of Anatomy, Antalya, Turkey
}

\begin{abstract}
Introduction: Open surgical procedures and endovascular aortic procedures are the most feared renal injuries in abdominal aortic surgery. The presence of renal anomalies and clear localization during aneurysm repair brings surgical success. In this article, we aimed to show the importance of renal anomalies in terms of mortality and morbidity in aneurysm repair.

Materials and Methods: Between January 2017 and January 2019, 250 patients with aortic aneurysm and CT angiography were included in the study. The files of the patients who underwent computerized contrast angiography for aortic aneurysm in Training and Research Hospital were reviewed retrospectively.

Results: Bilateral renal artery was detected in four male patients; and left accessory renal artery was detected in five male and three female patients. At the end of the study, 250 patients were screened; and bilateral renal arteries were detected in $1.6 \%$, left accessory arteries were detected in $3.2 \%$ of the eight patients.

Conclusions: It is important that surgeons and radiologists know the accessory arterial variations not only in abdominal aortic surgery, but also in recent years due to increased renal transplantation reconstruction, urological and radiological surgical techniques.
\end{abstract}

Key Words: Renal Artery Anomaly, Abdominal Aortic Aneurysm, EVAR, Renal insufficiency

\section{Introduction}

The kidneys reach their adulthood position embryologically at the ninth week; and as the kidneys take the adult position, the blood supply is provided by the branches that originate from the cranial end of the aorta abdominalis and the initial branches degenerate $(1,2)$.

Renal arteries originate from the abdominal aorta at the level of the intervertebral disc between the first and second lumbar vertebrae. These vessels

\section{ÖZET}

Amaç: Abdominal aort cerrahisinde açık cerrahi işlemler ve endovasküler aort girişimlerde en çok korkulan renal hasarlar olmasidir. Anevrizma tamiri esnasinda renal anomalilerin varlığ ve lokalizayonu net olarak bilinmesi cerrahi başarıyı beraberinde getirir. Bu makalede renal anomalilerin anevrizma tamirinde mortalite ve morbitide açısından önemini göstermeyi amaçladık.

Gereç ve Yöntem: Eğitim Araştırma Hastanemizde aort anevrizmas1 nedeniyle bilgisayarlı kontrastlı anjiografi uygulanan hastaların dosyaları retrospektif olarak incelenmiştir. Ocak 2017- Ocak 2019 tarihleri arasında elde edilmiş, 250 Aort Anevrizma tanısı olan ve BT anjio çekilen hastalar çalışmaya dahil edilmiştir.

Bulgular: Dört erkek hastada bilateral çift renal arter, beş erkek ve üç kadın hastada ise sol aksesuar renal arter tespit edilmiştir. Çalışmanın sonunda 250 hastalık taramada bilateral renal arter \%1,6 ve sekiz hastada sol aksesuar arter \%3,2 oranında hasta bulundu.

Sonuç: Akseuar arter varyasyonlarının, sadece abdominal aort cerrahisinde değil, son yillarda artan renal transplantasyon rekonstrüksiyon, ürolojik ve radyolojik cerrahi teknikler sebebiyle cerrahlar ve radyologlar tarafından iyi bilinmesi önem arz etmektedir.

Anahtar Kelimeler: Renal Arter Anomalisi, Abdominal Aort Anevrizmas1, EVAR, Renal yetmezlik

are generally at the level of L1 and L2 vertebrae, upper mesenteric artery just below the onset. Left renal artery is usually slightly higher than the right. Right renal artery is longer and passes under the vena cava inferior (3).

Each renal artery enters the hilum and is divided into anterior and posterior branches that feed the kidney parenchyma, then they are typically divided into four or more segmental branches (4). The accessory renal arteries, called the extrahedral artery, originate from the lateral side of the aorta, 


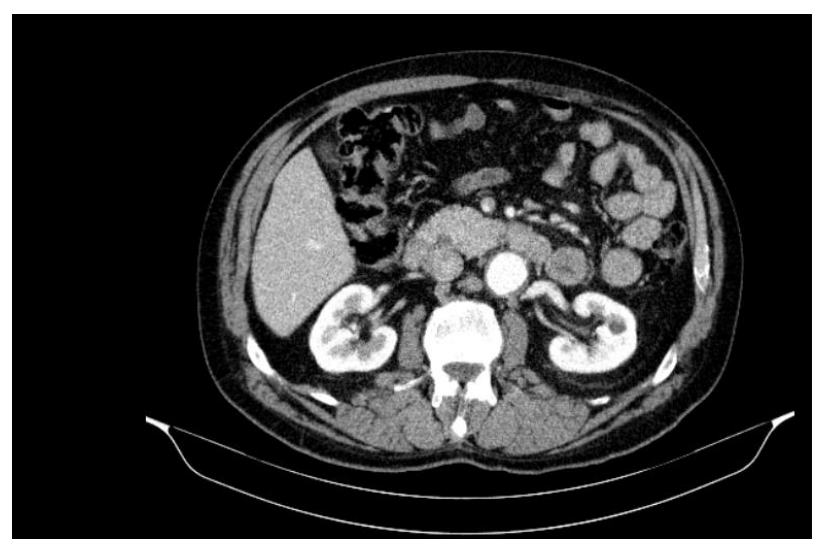

Fig. 1A. Double renal artery image on CT scan of aneurysm patient

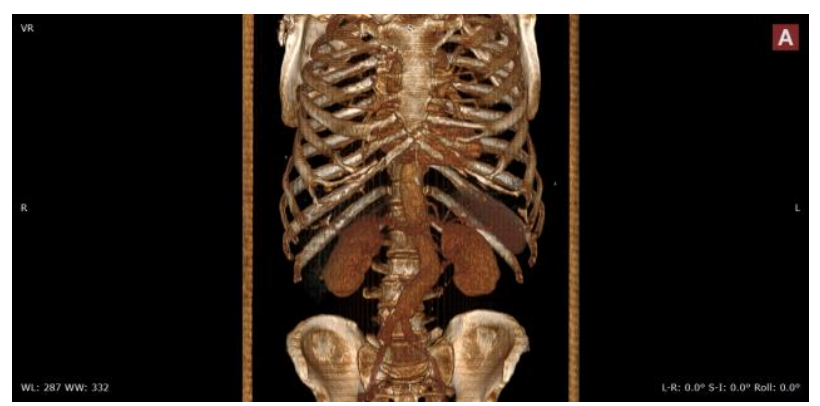

Fig. 1B. 3-D dual renal artery image of aneurysm patient

the top or bottom of the main renal arteries with the main renal arteries entering the kidney directly from the hilum or at various levels (3). It is clinically important that the accessory renal arteries do not anastomose with the branches of the main renal artery (5).

First description of accessory renal arteries was given in 1564 by Eustachi, and since then renal artery terminology has been controversial and unclear (6).

Abdominal aortic aneurysm (AAA) is defined as an abdominal aortic diameter of $3 \mathrm{~cm}$ or more at the infrarenal level. The incidence increases with age and 5\% over 65 years; and it is seen with a prevalence of $9 \%$ above 75 years of age. It ranks $13^{\text {th }}$ among all causes of death in studies conducted in the United States. AAA is the most common true aneurysm. The low medial elastin layer in the infrarenal region is a predisposing factor for aneurysm formation in this region. Risk factors for Familial Mediterranean Fever (FMF) development are age, male sex, smoking, hypertension, atherosclerotic cardiovascular disease; and dyslipidemia is a weak risk factor. There is also a familial incidence $(7,8)$.

Aneurysm diameter is very important in the management of abdominal aortic aneurysms. Aneurysms with a diameter of $4 \mathrm{~cm}$ or less have a

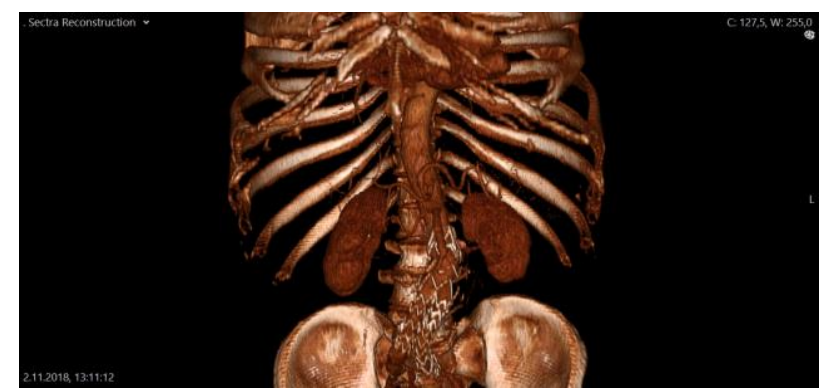

Fig. 2. CT image of a patient with renal artery variation treated with EVAR (Aneurysm diameter was $57 \mathrm{~mm}$.)

low chance of rupture (less than $1 \%$ per year) and should be followed. Despite the fact that the ruptured AAA has been around 50 years since the first successful surgical repair and considerable improvements have been made in surgical, anesthesia and intensive care conditions, it still causes high rates of mortality and morbidity, so it is of great importance (9). Aneurysms with an aneurysm diameter of $4-5.5 \mathrm{~cm}$ are controversial. UKSAT and ADAM studies suggested that aneurysm diameter should be waited until $5.5 \mathrm{~cm}$, while aneurysm diameter increased rapidly $(1 \mathrm{~cm}$ or more per year). Both studies were actually performed considering open surgical method. On the other hand, similar results were obtained in CEASAR and PIVOTAL studies with the introduction of endovascular method, and followup of aneurysms with a diameter of $4-5.5 \mathrm{~cm}$ was recommended. For aneurysms with a diameter of $5.5 \mathrm{~cm}$ or more, intervention is required when diagnosed. It should be noted that the higher the diameter of the aneurysm, the higher the chance of rupture (10-15).

Although abdominal aortic aneurysms are mostly located in the infrarenal region, renal artery and veins are very important because they extend in the suprarenal region. In recent years, many conservative surgical methods related to renal artery have emerged. Therefore, the exact course of renal artery has become a necessity. It is important to know the presence of accessory renal arteries; otherwise, they may be damaged during kidney surgery. In addition, the presence of additional arteries should be considered when evaluating a donor's kidney for a possible kidney transplant (16). This is important for the possibility of the presence of accessory renal artery extending to the suprarenal region in the operations performed for abdominal aortic aneurysms. In our study, we aimed to evaluate the renal artery variations in patients with aortic aneurysm and to provide an idea of how these can be reflected in the clinic. 


\section{Materials and Methods}

In this study, files of patients who underwent computerized contrast angiography for aortic aneurysm in Training and Research Hospital were retrospectively analyzed. Between January 2017 and January 2019, 250 patients with aortic aneurysm and CT angiography were included in the study. Bilateral renal artery was detected in four male patients and left accessory renal artery was detected in five male and three female patients (Table 1) (Figure 1a-1b) (Figure 2). This study was approved by the local ethics committe of scientific researches of Faculty of Medicine (2019/10/5).

\section{Results}

In the study; A retrospective review of patients with aortic aneurysm and contrast-enhanced tomography was conducted. At the end of the study, 250 patients were screened in $1.6 \%$ of bilateral renal arteries and $3.2 \%$ of left accessory arteries in eight patients. According to the literature, the reason for the low incidence of variation in a.renalis are the retrospective screening of the patients with aortic aneurysms and the fact that the patient group is in the 45-85 age range; therefore, not covering the whole population.

\section{Discussion}

The frequency of extra renal arteries (ERA) shows variability from $9 \%$ to $76 \%$; and is generally between $28 \%-30 \%$ in anatomic and cadaver studies (1).

In a study by Ozkan et al., $76 \%$ of 855 patients had single a.renalis, and $24 \%$ had more than one a.renalis. The presence of one single a.renalis was detected in $713(83 \%)$ cases in the right kidney, and two a.renalis were detected in $126(15 \%)$ cases, three a.renalis were detected in $9(1 \%)$ cases. One a.renalis was reported in the left kidney in $736(86 \%)$ cases, two in $105(12 \%)$ cases, three in $6(0.7 \%)$ cases, and four in $2(0.2 \%)$ cases. In 46 $(5 \%)$ cases, more than one a. renalis was reported (1).

Gumus et al. performed an MDCT angiography examination with 820 people, and found a $27 \%$ extrarenal artery. Renal artery variation is seen in approximately one quarter of this study population (17).
In the study performed by Cicekcibasi et al. on 90 fetuses, $75 \%$ had a single a.renalis, $11.1 \%$ had double a.renalis, $10.5 \%$ had lower pole artery, and $3.3 \%$ had upper pole artery. Anatomical variations have been reported more frequently in male fetuses and on the right side (18).

Unilateral double renal vessels were reported by Mohammed in 2012 (16). Bilateral duplication of renal vessels was reported by Bordei et al. (17) in 2004 and by Mir et al. (18) in 2008. The same was also observed in the present study. Bilateral triple renal arteries were observed by Pestemalci et al. (4) in 2009.

When renal artery variations are clinically evaluated; knowing the anatomical variations of renal vessels is important in the surgical treatment of conditions such as kidney transplantation, congenital or subsequent vascular lesions and abdominal aortic aneurysm. It is also of special importance, since the morphology of the renal veins in the kidney transplant will greatly affect the technical aspect of the surgery $(19,20)$.

Ersoz et al. stated that; more than one renal artery is a disadvantage in kidney transplantation (21). Yalın et al. reported that the renal arteries are "end arteries", and when they are attached, necrosis, ulceration and fistulas may occur in the kidney tissue they feed (22).

In addition, it is stated in the literature that extra renal arteries may cause dilatation and hydronephrosis over time due to their pressure on their neighborhood (23).

Precise knowledge of the most frequent types of renal vascular anatomical variations is needed due to the continuous growing and development of surgical procedures such as renal transplants, aneurysms repair, oncologic partial nephrectomy, ablation treatment for refractory hypertension and vascular reconstructions $(6,24)$.

As a result, it will help surgeons to know the renal artery variations in patients with abdominal aortic aneurysms and compare the incidence compared to the normal population, especially during abdominal surgical approaches and radiological examinations.

Considering the increasing number of malpractice cases and the resulting defensive surgery in recent years, even a patient is of great importance. Since abdominal surgery is the most feared renal injury in open surgical procedures and endovascular aortic procedures, renal arteries are of great importance in both surgical procedures. The position of renal arteries during aneurysm repair is very important. The surgical margin is determined 
Etli et al. / Accessory Renal Artery In Aortic Aneurysms

Table 1. Demographic characteristics of patients with accessory renal artery in aortic aneurysms

\begin{tabular}{lccccccc}
\hline Gender & Age & $\begin{array}{c}\text { Aortic } \\
\text { Diameter }\end{array}$ & Diabetes & Smoking & Hypertension & $\begin{array}{c}\text { Left Accessory } \\
\text { Renal Artery }\end{array}$ & $\begin{array}{c}\text { Bilateral } \\
\text { Renal Artery }\end{array}$ \\
\hline Male & 63 & 57 & - & + & + & - & + \\
Male & 45 & 48 & - & + & - & - & + \\
Male & 43 & 45 & - & + & - & - & + \\
Male & 55 & 51 & - & - & + & - & + \\
Male & 43 & 50 & - & - & - & + & - \\
Male & 63 & 52 & - & + & - & + & - \\
Male & 66 & 48 & + & + & - & + & - \\
Male & 72 & 53 & - & - & + & + & - \\
Male & 68 & 46 & - & - & - & + & - \\
Female & 49 & 45 & + & - & + & + & - \\
Female & 70 & 50 & - & - & - & + & - \\
Female & 54 & 47 & - & - & + & + & + \\
\hline
\end{tabular}

according to the position of the right and left renal artery. However, while the position of the renal artery is very important in surgery, it is not considered that it may be an accessory renal artery and perhaps postoperative renal dysfunction may result from an accessory renal artery being closed during the operation.

In addition, it is important to know the accessory artery variations by radiologists and surgeons not only in abdominal aortic surgery but also in recent years due to increasing renal transplantation reconstruction, urological and radiological surgical techniques.

\section{References}

1. Ozkan U, Oguzkurt L, Tercan F, Kizilkilic O, Koc Z, Koca N. Renal artery origins and variations: angiographic evaluation of 855 consecutive patients. Diagnostic and interventional radiology (Ankara, Turkey) 2006; 12(4): 183-186.

2. Satyapal KS, Haffejee AA, Singh B, Ramsaroop L, Robbs JV, Kalideen JM. Additional renal arteries: incidence and morphometry. Surgical and radiologic anatomy : SRA 2001; 23(1): 33-38.

3. Richard Drake WV. Gray's Anatomi. Gunes Medical Bookstore 2017: 324.

4. Pestemalci T, Mavi A, Yildiz YZ, Yildirim M, Gumusburun E. Bilateral triple renal arteries. Saudi journal of kidney diseases and transplantation : an official publication of the Saudi Center for Organ Transplantation, Saudi Arabia 2009; 20(3): 468-470.

5. Moore KL DA. Clinically Oriented Anatomy. Lippincott Williams \& Wilkins Publishers 1999: 286-287.
6. Gulas E, Wysiadecki G, Szymański J, Majos A, Stefańczyk L, Topol M, et al. Morphological and clinical aspects of the occurrence of accessory (multiple) renal arteries. Arch Med Sci 2018; 14(2): 442-453.

7. Bobadilla JL, Kent KC. Screening for abdominal aortic aneurysms. Advances in surgery 2012; 46: 101-109.

8. Peach G, Holt P, Loftus I, Thompson MM, Hinchliffe R. Questions remain about quality of life after abdominal aortic aneurysm repair. Journal of vascular surgery 2012; 56(2): 520-527.

9. Kutay V., Ekim H., Karadağ M., C. Y. Retroperitoneal Bölgeye Rüptüre Olmuş Dev Abdominal Aort Anevrizması Cerrahi Onarımı: (Olgu Sunumu). Van Tip Dergisi 2004; 11(1): 2931.

10. Long A, Rouet L, Lindholt JS, Allaire E. Measuring the maximum diameter of native abdominal aortic aneurysms: review and critical analysis. European journal of vascular and endovascular surgery : the official journal of the European Society for Vascular Surgery 2012; 43(5): 515-524.

11. Filardo G, Powell JT, Martinez MA, Ballard DJ. Surgery for small asymptomatic abdominal aortic aneurysms. The Cochrane database of systematic reviews 2015(2): Cd001835.

12. Ouriel K. Randomized clinical trials of endovascular repair versus surveillance for treatment of small abdominal aortic aneurysms. Journal of endovascular therapy : an official journal of the International Society of Endovascular Specialists 2009; 16(1):I94-105.

13. De Rango P, Verzini F, Parlani G, Cieri E, Romano L, Loschi D, et al. Quality of life in patients with small abdominal aortic aneurysm: the effect of early endovascular repair versus surveillance in the CAESAR trial. European 
journal of vascular and endovascular surgery : the official journal of the European Society for Vascular Surgery 2011; 41(3): 324-331.

14. Brown LC, Thompson SG, Greenhalgh RM, Powell JT. Fit patients with small abdominal aortic aneurysms (AAAs) do not benefit from early intervention. Journal of vascular surgery 2008; 48(6): 1375-1381.

15. Buckley CJ, Rutherford RB, Diethrich EB, Buckley SD. Inherent problems with randomized clinical trials with observational/no treatment arms. Journal of vascular surgery 2010; 52(1): 237 241.

16. Ali Mohammed AM, Elseed Abdalrasol RG, Alamin Abdalhai K, Gommaa Hamad M. Accessory renal vessels. Acta Inform Med 2012; 20(3): 196-197.

17. Bordei P, Sapte E, Iliescu D. Double renal arteries originating from the aorta. Surgical and radiologic anatomy : SRA 2004; 26(6): 474-479.

18. Mir NS, Ul Hassan A, Rangrez R, Hamid S, Sabia, Tabish SA, et al. Bilateral Duplication of Renal Vessels: Anatomical, Medical and Surgical perspective. Int J Health Sci (Qassim) 2008; 2(2): 179-185.

19. Koşar Mİ, Erdil FH, Sabancioğulları V, M. Ç. Sağda çift arteria renalis ve çift vena renalis olgusu. Cumhuriyet Med Journal 2009; 31: 283 287.

20. İmre N YF, Ozan H. . Çift arteria renalis ile çift vena renalis kliniği: Olgu sunumu. Damar Cer Derg 2017; 26(3): 120-124.

21. Ersoz S, Tuzuner A, Erkek B, Esen S, Anadol E. Double renal arteries in living-related kidney transplantation. Transplantation proceedings 2000; 32(3): 604.

22. Yalın A, Gümüşburun E, O. C. Multipl renal arter (Bir olgu sunumu). C Ü Tip Fak Derg 1988; 10: 152-158.

23. Williams PL DM. Gray's Anatomy: London: Churchill Livingstone 1995; 1407-1557.

24. Mendes BC, Oderich GS, Reis de Souza L, Banga P, Macedo TA, DeMartino RR, et al. Implications of renal artery anatomy for endovascular repair using fenestrated, branched, or parallel stent graft techniques. Journal of vascular surgery 2016; 63(5): 1163-1169.e1161. 